\title{
IDENTIFIKASI KENDALA PEMBIAYAAN KOMODITAS PERTANIAN SISTEM RESI GUDANG DI INDONESIA
}

\section{Constraints Identification for the Financing of Agricultural Commodity Warehouse Receipt System in Indonesia}

\author{
Karmex Siadari ${ }^{1}$, M.Syamsul Maarif ${ }^{1}$, Bustanul Arifin ${ }^{2}$, Zulkifli Rangkuti ${ }^{3}$ \\ ${ }^{1}$ School of Business, IPB University, Jl. Pajajaran, Bogor, Jawa Barat, 16151, Indonesia \\ 2 Departemen Ilmu Ekonomi Pertanian dan Ilmu Sosial, Universitas Lampung dan \\ Institute for Development of Economics and Finance (INDEF), Indonesia \\ ${ }^{3}$ Sekolah Tinggi Manajemen IMMI Jakarta, Jl. Tanjung Barat No.11 Jakarta Selatan, \\ 12510 , Indonesia. \\ Email: max.siadari@yahoo.com
}

Naskah diterima: 27/01/2021; Naskah direvisi: 17/06/2021; Disetujui diterbitkan: 04/07/2021; Dipublikasikan online: 24/12/2021

\begin{abstract}
Abstrak
Pembiayaan komoditas pertanian sistem resi gudang belum berlangsung sesuai harapan di Indonesia. Hal tersebut menurut beberapa studi karena masih banyak permasalahan penghambat. Studi ini mengidentifikasi kendala pembiayaan komoditas pertanian sistem resi gudang di Indonesia. Penelitian dilakukan melalui wawancara mendalam terhadap responden tertentu yang memiliki pengetahuan atau pengalaman pada pembiayaan komoditas pertanian berbasis sistem resi gudang yang diimplentasikan terhadap komoditas pertanian seperti kopi, lada, beras dan jagung. Data yang dikumpulkan diidentifikasi, dikelompokkan dan diklasifikasikan secara terstruktur di dalam pola berfikir strategis dan dianalisa secara analisa deskriptif. Penelitian ini berhasil menemukan faktor penghambat pembiayaan komoditas pertanian sistem resi gudang di Indonesia antara lain: ketidaksesuaian nilai manfaat yang dibangun dengan karakteristik petani di Indonesia khususnya petani kecil; keterbatasan sumber layanan, ketidakcocokan skema dan fitur pembiayaan, harga pembiayaan dan skala ekonomi petani, suplai informasi yang memengaruhi kesadaran pada pembiayaannya. Permasalahan tersebut harus dapat diminimalisasi sehingga meningkatkan aksesibilitas dan kelangsungan pembiayaan sistem SRG pada petani di Indonesia.
\end{abstract}

Kata kunci: Pembiayaan Komoditas Pertanian, Kendala, Sistem Resi Gudang

\begin{abstract}
Agricultural commodity financing in the warehouse receipt system has not performed as expected in Indonesia. According to several studies, it is due to many obstacles hindering the system to grow. This study identifies the constraints on agricultural commodities financing on the warehouse receipt system. The research was conducted through in-depth interviews with certain respondents who have knowledge or experience in agricultural commodities financing based on a warehouse receipt system implemented on agricultural commodities such as coffee, pepper, rice, and maize. The collected data are identified, grouped, and classified in a structured manner in the pattern of strategic thinking and analyzed by descriptive analysis. The study succeeded to identify the barriers that hindering agricultural commodities financing in warehouse receipt system to grow in Indonesia: the incompatibility of the value built with the characteristics of agriculture business, especially for small farmers; limited financing sources, incompatibility of financing schemes and features, financing prices and farmer economies of scale and supply of information that affects awareness of financing. These problems must be minimized to encourage the accessibility and continuity of financing on WRS for farmers in Indonesia.
\end{abstract}

https://doi.org/10.30908/bilp.v15i2.555

Published by Trade Analysis and Development Agencies, Ministry of Trade. This is an open access article under the CC BY-NC-SA 4.0 license (http://creativecommons.org/licenses/by-nc-sa/4.0/) 
Keywords: Agricultural Commodity Financing, Contraints, Warehouse Receipt System JEL Classification: D46, F6, F61, F65, Q14

\section{PENDAHULUAN}

Akses pembiayaan merupakan hal penting untuk mendukung usaha pertanian. Kemudahan akses pembiayaan secara teori dapat meningkatkan kinerja dan mendorong investasi dan pertumbuhan usaha lebih cepat (Nyanzu \& Quaidoo, 2017). Akses pembiayaan pada sektor pertanian di beberapa negara termasuk di Indonesia sejak masa lalu hingga waktu belakangan ini masih menghadapi berbagai kendala. Pembiayaan komoditas pertanian, sebuah konsep pembiayaan di bagian hilir usaha pertanian merupakan sistem pembiayaan alternatif yang secara konsep memiliki keunggulan dan dapat mengurangi kendala klasik pembiayaan pada usaha pertanian seperti kendala jaminan, likuiditas dan kemudahan persyaratan pembiayaan (Abubakar et al. 2017). Prinsip dasar pembiayaan komoditas adalah barang hasil pertanian atau komoditas pertanian sebagai jaminan utama dan sumber pelunasan kembali pinjaman.

Konsep pembiayaan komoditas telah berkembang dengan berbagai pendekatan seperti sistem pembiayaan sistem resi gudang atau warehouse receipt financing system (Varangis \& Larson, 2002; Sutak, 2008; Miranda, 2017). Struktur pembiayaan dibangun dalam tiga elemen utama, konsumen pemilik barang atau dagang sebagai konsumen peminjam (debitur) yang menggunakan barang komoditas hasil pertanian sebagai jaminan dan sumber pembayaran kembali pinjaman, institusi pendukung sebagai syarat membangun sistem resi gudang misalnya pengelola barang atau jaminan, pengelola gudang dan pasar komoditas, serta institusi pembiayaan sebagai sumber layanan pembiayaan (gambar 1).

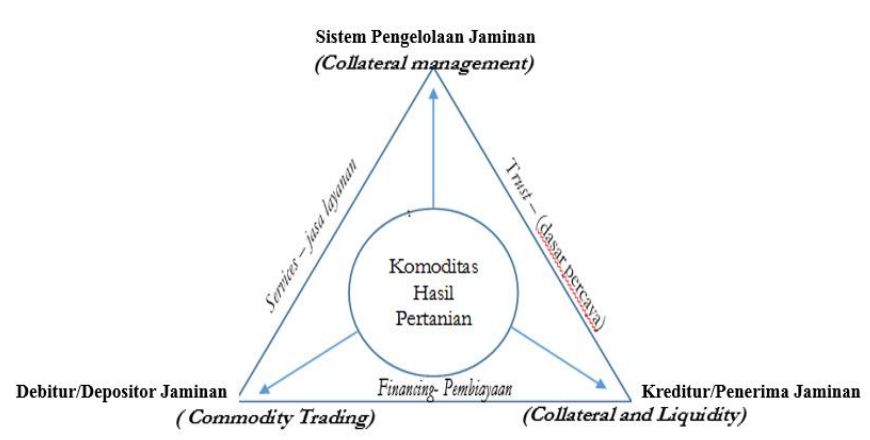

\section{Gambar 1. Skema Dasar Pembiayaan Komoditas Sistem Resi Gudang}

Sumber: Varangis \& Larson (2002); Varangis \& Geours (2013), diolah

Pembiayaan komoditas pertanian sistem resi gudang berdasarkan beberapa studi berhasil dikembangkan 
di beberapa negara. Sistem resi gudang awalnya dikembangkan di Chicago di antara tahun 1830 dan tahun 1850 sebagai bukti penerima hasil petani gandum dan komoditas lain, dan menyimpannya dalam jumlah yang besar, menjual terlebih dahulu atau jual di muka dengan mengeluarkan resi gudang sebagai bukti keberadaan barang atau persediaan yang diperjual belikan. Selanjutnya, The Chicago Board of Trade (CBOT) memunculkan resi gudang sebagai dasar perdagangan komoditas dan sistem perdagangan untuk menyatakan informasi terkait gandum yang diperdagangkan, dan sejak akhir tahun 1860-an negara bagian Illinois membuat undang-undang untuk mengatur sistem resi Gudang (Mahanta, 2012; Miranda et al, 2017). Sistem resi gudang kemudian berkembang ke berbagai negara, dan pada beberapa dekade terakhir berkembang seperti di Argentina, Brazil Hungaria, Bulgaria dan Kazakhstan Afrika dan Uganda. Sistem tersebut berkembang dan dinyatakan memberikan dampak positif seperti kemudahan akses pembiayaan dan membantu pengembangan usaha masyarakat petani kecil dan menengah di berbagai negara.
Situasi pembiayaan komoditas sistem resi di Indonesia memberikan gambaran berbeda. Pembiayaan komoditas telah dikenal sejak lama, awalnya dikembangkan dengan sistem pengawasan jaminan barang komoditas di gudang melalui double locked system atau penguasaan barang di gudang melalui penguasaan kunci gudang jaminan oleh pihak bank pemberi pinjaman dan debitur penerima pinjaman. Pembiayaan komoditas kemudian berkembang pada sistem resi gudang yang dikembangkan dalam dua pendekatan. Pertama, pembiayaan komoditas sistem resi gudang dengan skema perjanjian kontrak tiga pihak (tripartite) untuk pengelolaan jaminan atau Collateral Management Agreement (CMA). Sistem tersebut sempat berkembang di perbankan komersial asing seperti Rabobank, DBS, Deuche Bank, dan HSBC dan perbankan komersial nasional seperti BRI, Mandiri dan Bank Mega yang disalurkan pada pembiayaan beberapa komoditas dagang misalnya komoditas pertanian seperti Kopi, Lada dan Coklat dan berbagai komoditas pertanian dan non pertanian lainya. Berdasarkan data pengecekan ke beberapa sumber pada pada tahun 2008 volume pembiayaan pada komoditas dagang dengan sistem 
CMA mencapai lebih dari 5 Triliun Rupiah, walaupun setelah tahun 2008 yang ditengrai dipicu oleh krisis finansial tahun 2008 berdampak pada penurunan harga beberapa komoditas pertanian dan meningkatnya kredit bermasalah khususnya pada pembiayaan komoditas. Kedua, skema pembiayaan komoditas dengan sistem formal disebut Sistem Resi Gudang (SRG). Sistem ini telah berlangsung sejak tahun 2006 tetapi belum berlangsung secara optimal. Pembiayaan komoditas pertanian dengan transaksi sistem resi gudang hingga tahun 2020 masih relatif rendah $(<1 \%)$ apabila dibandingkan dengan potensi produksi komoditas pertanian di Indonesia misalnya kopi, lada, beras dan jagung (Sesuai data KBI 2020). Layanan tersebut umumnya disalurkan kepada kelompok petani penghasil komoditas skala usaha kecil seperti petani mandiri, kelompok tani (poktan) atau gabungan kelompok tani (gapoktan) atau koperasi petani (koptan) pada pembiayaan beberapa komoditas pertanian seperti beras dan jagung. Pembiayaan komoditas sistem resi gudang umumnya disalurkan melalui perbankan nasional misalnya BRI, Bank Jabar dan Bank Jatim.

Penelitian terdahulu tentang SRG di Indonesia mengidentifikasi beberapa temuan tentang permasalahan sistem resi gudang. Suryani, et al. (2014) menyatakan nilai manfaat sistem resi gudang karena belum sesuai harapan masyarakat. Ashari (2012) menyatakan kelembagaan pada usaha tani belum memadai, Listiani (2013), Bustamin (2014) dan Gunawan et al, (2019) menyatakan kurangnya pengetahuan masyarakat tentang sistem resi gudang merupakan penghambat sistem itu berkembang. Penelitian-penelitian di atas lebih ditonjolkan pada permasalahan sistem resi gudang sebagai sistem penyimpanan barang komoditas sedangkan pada aspek pembiayaan masih kurang terekplorasi.

Penelitian lain yang mengamati sistem resi gudang dan pembiayaannya di negara lain misalnya pada jurnal Coulter \& Onumah (2002), Sutak (2008), Gashayie \& Singh (2015), Rutten (2015), Swamy \& Dharani (2016) dan Miranda et al, (2017) mengambarkan dimensi permasalahan yang kompleks tentang pembiayaan sistem resi gudang, Permasalahan yang dijumpai relatif berbeda-beda misalnya permasalahan kelembagaan, hukum, infrastruktur, sistem informasi dan struktur pasar, permasalahan nilai manfaat, dan lemahnya kepercayaan. Informasi di atas menggambarkan 
karakteristik pembiayaan dan kendala pembiayaan sistem resi gudang bervariasi sesuai dengan kondisi lingkungan di masing-masing negara.

Kendala menurut James \& Michael (1998) adalah sesuatu yang menyebabkan perusahaan tidak memungkinkan dilaksanakan dan mencapai sasaran, kendala dapat disebabkan oleh berbagai aspek dan dapat terjadi pada seluruh elemen organisasi, sistem dan produk yang menghambat perusahaan untuk mencapai tujuan. Elemen kendala pembiayaan sistem resi gudang di atas apabila ditinjau dari teori produk dan pemasaran mengindikasikan adanya kesenjangan nilai manfaat produk (Kotler \& Keller, 2009), keterbatasan pada atribut pemasaran dan distributsi produk (Sheth \& Sisodia, 2012) dan ketidakseimbangan informasi yang memengaruhi kepercayaan pada produk (Stiglitz \& Weiss, 1981; Becchetti \& Conzo, 2009; Capacio et al., 2018).

Kesenjangan diartikan sebagai ketidaksesuaian nilai produk antara yang dijanjikan dengan yang dipersepsikan sebagai nilai aktual nilai. Penilaian pada layanan pembiayaan dapat berbeda-beda sesuai skala usaha (Capacio et al., 2018). Nilai manfaat pembiayaan pada bisnis korporasi berbeda dengan perusahaan skala mikro, kecil dan menengah. Karakteristik usaha mikro kecil dan korporasi berbeda. Usaha kecil dan menengah memiliki keterbatasan pada aspek likuiditas (liquidity), ketersediaan jaminan (Collateral), kemampuan membayar biaya bunga (Interest bearing) dan kurang ahli mengelola keuangan (Hananu et al., 2015).

Keterbatasan, Keterbatasan menjangkau produk (product constrains), meliputi seluruh atribut yang melekat pada produk yang dapat membatasi konsumen memperoleh produk (Capacio et al., 2018). Keterbatasan adalah sebagai sesuatu kondisi yang menghambat untuk mencapai tujuan. Menurut Reyes et al. (2012 P:5) dalam konteks pembiayaan, keterbatasan adalah sebuah kondisi individu tertentu dapat mengakses pinjaman sementara individu lain dengan persyaratan yang sama tidak dapat mengakses pembiayaan itu (Becchetti \& Conzo, 2009). Menurut Stiglitz \& Weiss (1981) keterbatasan dan pembatasan dapat bersumber dari dalam dan luar perusahaan dan dipengaruhi oleh latar belakang kepentingan yang berbeda. Lembaga perbankan sebagai lembaga perantara atau intermediary keuangan memiliki 
ketentuan, pertimbangan dan batasanbatasan eksternal yang memengaruhi keputusannya ketika membangun produk dan menyalurkan pembiayaannya. Penetapan pembatasan atau ketentuan produk tersebut selanjutnya menjadi kendala bagi konsumen bila tidak sanggup memenuhi batasan yang dibangun (Gashayie \& Singh, 2015).

Ketidakseimbangan informasi atau asimetri informasi (information assymentry) adalah ketidakseimbangan infomasi yang dimiliki masyarakat. Informasi yang dimiliki menentukan sikap dan kesadaran stakeholder terhadap produk yang ditawarkan (Sheth \& Sisodia, 2012). Informasi yang dimiliki juga menjadi dasar pertimbangan dan menentukan keinginan masing-masing. Stiglitz \& Weis (1981) menyatakan tingkat kepercayaan pada produk ditentukan kelengkapan informasi dan pengetahuan yang diperoleh masingmasing pihak dari sumber internal atau eksternal. Ketidakseimbangan informasi dapat menyebabkan kurangnya pengetahuan, pemahaman dan keinginan yang berbeda bahkan bergerak bertolak belakang (Capacio et al., 2018)
Berdasarkan gambaran diatas, penelitian ini bertujuan untuk mengidentifikasi permasalahan pembiayaan komoditas pertanian sistem resi gudang di Indonesia pada aspek pembiayaan. Melalui identifikasi permasalahan pembiayaan komoditas sistem SRG secara teori dapat membantu dalam menentukan faktor penghambat produk berkembang. Pada penelitian ini identifikasi kendala pembiayaan komoditas pertanian sistem resi gudang dibatasi pada pembiayaan komoditas yang secara nyata telah terimplementasi seperti pada komoditas kopi, lada, beras dan jagung.

\section{METODE}

Identifikasi kendala pembiayaan sistem resi gudang diawali dengan penelitian faktor-faktor penentu yang memengaruhi penerimaan atau akseptabilitas pada produk pembiayaan komoditas sistem resi gudang sebagaimana pada penelitian awal Siadari (2021). Terdapat multi faktor yang menentukan penerimaan konsumen pada pembiayaan. Faktor ideal tersebut merupakan kondisi yang diharapkan debitur dan dibandingkan dengan kondisi yang dialami atau dipersepsikan pada dunia nyata. Perbedaan kondisi ideal yang diharapkan dengan dipersepsikan 
disebut sebagai kesenjangan atau gaps (Purnama, 2006). Kesenjangan tersebut berdasarkan teori dibedakan menjadi kesenjangan nilai meliputi nilai ekonomis, nilai sosial dan lingkungan; keterbatasan pada atribut pemasaran dan distribusi produk meliputi ketersediaan, keterjangkauan, kesesuaian, dan kesanggupan; dan tingkat kesenjangan informasi yang menentukan kepercayaan stakeholder dipengaruhi oleh kelengkapan informasi (Gambar 2). Indentifikasi kendala pada studi ini dikembangkan dalam pola fikir strategis diawali dengan pengumpulan data, identifikasi, pengelompokan dan pengklasifikasian masalah (Ohmae \& Kenichi, 1982).

\begin{tabular}{|c|c|}
\hline Product Expectation & Product - Gaps \\
\hline \hline Product Value & Value Gaps \\
\hline Product Attributes & Product Contraints \\
\hline Product Trustworhiness & Product Value \\
\hline Product
\end{tabular}

\section{Gambar 2. Konsep Penilaian Kesenjangan Produk Pembiayaan}

Penelitian dilakukan kepada kelompok pemangku kepentingan pembiayaan komoditas pertanian sistem resi gudang yang merepresentasikan antara lain: kelompok masyarakat konsumen pemakai jasa pembiayaan seperti petani atau koperasi petani, kelompok pengumpul atau pedagang komoditas pertanian; kelompok institusi jasa layanan pembiayaan (perbankan) dan institusi pendukung pengembangan sistem resi gudang seperti pengelola gudang, pengelola jaminan, badan registrasi jaminan dan asuransi. Pengambilan data dilakukan di beberapa wilayah Jawa dan Sumatera dengan berbagai tingkat pengalaman dalam menjalankan pembiayaan sistem resi gudang baik yang sukses maupun yang bermasalah. Pengambilan data dilakukan pada Agustus 2019 hingga Januari 2020.

Jenis dan sumber data yang digunakan dalam penelitian ini terdiri dari, pertama, data primer diperoleh melalui wawancara mendalam (in depth interview) menggunakan media kuesioner sebagai alat bantu untuk menangkap informasi permasalahan yang dihadapi responden dalam mengimplementasikan sistem resi gudang dan pembiayaanya pada beberapa komoditas di beberapa lokasi lokasi penelitian. Pengumpulan data 
primer melibatkan responden yang dipilih secara purposif mewakili stakeholder kelompok petani penghasil komoditas, kelompok pengumpul/ pedagang lokal, institusi perbankan dan institusi pendukung terkait pembiayaan sistem resi gudang pada komoditas kopi, lada, beras dan jagung.

Responden dipilih memiliki kriteria yang minimal yang ditetapkan antara lain: berpendidikan minimal SMA, memiliki pengalaman sebagai pengguna atau debitur pembiayaan sistem resi gudang, penyedia layanan pembiayaan sistem resi gudang, penyedia sistem pengelola jaminan pembiayaan komoditas sistem resi gudang dan institusi pendukung lainya yang terkait pembiayaan sistem resi gudang minimal satu tahun. Kedua, data sekunder adalah data-data yang diperoleh dari berbagai sumber yang representatif memberikan informasi terkait pembiayaan komoditas sistem resi gudang dan pembiayaannya.

Data yang terkumpul dianalisis dengan metode analisa deskriptif untuk menggambarkan tabulasi masalah yang dihadapi. Metode analisis deskriptif dengan pendekatan kualitatif dilakukan untuk mendeskripsikan suatu gejala, peristiwa dan kejadian yang terjadi pada saat sekarang dimana peneliti berusaha memotret peristiwa dan kejadian yang menjadi pusat perhatian. Penggunaan metode deskriptif untuk memusatkan pada masalah aktual atau fenomena yang sedang terjadi dibandingkan dengan kondisi ideal atau faktor faktor yang telah didefinisikan sebagaimana pada karakterisasi pembiayaan komoditas sistem resi gudang (Siadari, 2021). Persamaan arah disebut sebagai arah kesesuaian apabila kondisi ideal dengan kondisi aktual yang dialami atau dipersepsikan dan perbedaan keduanya disebut sebagai kesenjangan atau perbedaan kondisi aktual yang dialami atau dipersepsikan.

\section{HASIL DAN PEMBAHASAN}

Data kendala pembiayaan komoditas sistem resi gudang dikumpulkan melalui wawancara secara langsung terhadap 40 responden yang memenuhi kualifikasi sebagai responden penelitian antara lain: Pertama, kelompok konsumen produk layanan pembiayaan komoditas antara lain kelompok petani, gabungan kelompok tani dan koperasi petani produsen komoditas yang beraksi sebagai konsumen pembiayaan sistem resi gudang di pada komoditas seperti beras, jagung, kopi dan lada di beberapa 
wilayah jawa barat seperti Cianjur, Tasikmalaya dan Subang; wilayah Jawa Tengan seperti Grobogan; wilayah provinsi Lampung seperti Natar, Candipuro dan Liwa. Kedua, kelompok institusi perbankan yang telah berpengalaman pada pembiayaan komoditas yang berlokasi di Jakarta seperti Rabobank, HSBC, UOB, SCB, CIMB Niaga, Bank Mega, BRI dan BJB. Ketiga, kelompok institusi pengelola jaminan komoditas dan institusi pendukung sistem resi gudang seperti Pusat Registrasi Sistem Resi Gudang dan perusahaan Asuransi yang berlokasi di Jakarta. Keempat, pengumpul atau pedagang komoditas lokal di Surabaya Provinsi Jawa Timur, Lampung dan Medan Provinsi Sumatera Utara. Data permasalahan tersebut dikumpulkan, dikelompokkan sesuai kesamaan permasalahan dan kemudian diklasifikasikan pada sesuai dimensi permasalahannya (Gambar 3).

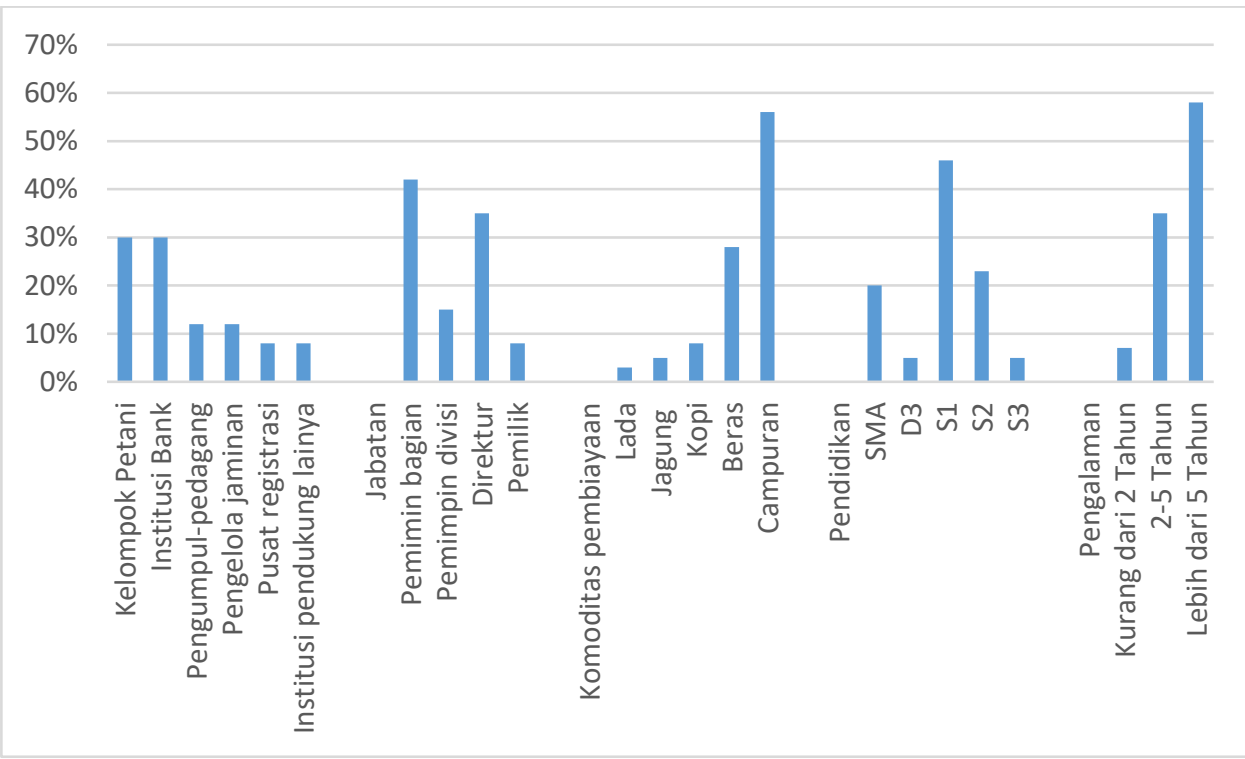

Gambar 3. Gambaran Responden dan Komoditas Pembiayaan

Komposisi responden sebagai Kedua, jabatan responden di dalam berikut: Pertama, berdasarkan jenis organisasi perusahaan sebagai: usaha dan terkait dengan sistem resi gudang: sebagai kelompok tani/koperasi tani $30 \%$, perbankan $30 \%$, pengumpul atau trader $12 \%$; pengelola jaminan $12 \%$; pusat registrasi $8 \%$ dan institusi pendukung lainya seperti asuransi $8 \%$. pemimpin bagian $43 \%$, direktur $34 \%$, pemimpin divisi $15 \%$ dan pemilik $8 \%$. Ketiga, komoditas yang dibiayai dalam sistem resi gudang kopi $8 \%$, lada $3 \%$, beras $28 \%$, jagung $5 \%$ dan campuran beberapa komoditas 56\%. Keempat, 
tingkat pendidikan responden SMA (20\%), D3 (6\%), S1 (6\%), S2 (23\%) dan S3 $(5 \%)$ dan Kelima, lama pengalaman responden pada pembiayaan atau sistem resi gudang: Kurang dari 2 tahun (7\%), 2-5 tahun (35\%) dan lebih dari 5 tahun (58\%).
Identifikasi dan pengelompokan masalah

Pengamatan kepada 40 responden diperoleh 249 isu permasalahan pembiayaan komoditas sistem resi gudang dan dikelompokkan ke dalam 13 kelompok masalah utama berdasarkan kesamaan isu (Gambar 4).

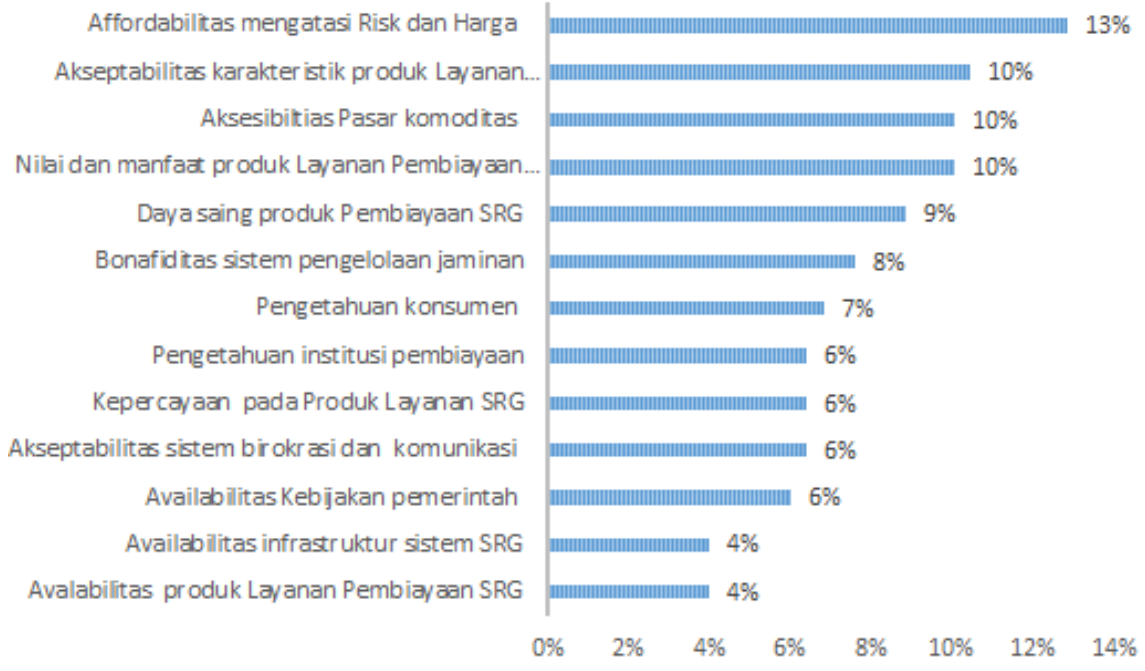

\section{Gambar 4. Pengelompokan Permasalahan Pembiayaan Komoditas Sistem Resi Gudang}

Kelompok permasalahan tersebut beragam dan bersumber dari berbagai stakeholder dengan kesamaan isu yang tersebar di sekitar lingkungan sistem pembiayaan. Stakeholder secara bebas memberikan pendapat, data dan informasi sesuai pengalaman dan pengetahuannya. Berdasarkan Gambar 4, permasalahan utama dapat diklasifikasikan berdasarkan kelompok isu yang ditemui antara lain: permasalahan mengatasi risiko harga komoditas, (ii) permasalahan karakteristik (struktur/skim) produk pembiayaan komoditas, permasalah ketersediaan pasar komoditas, (iv) permasalahan nilai manfaat atau insentif produk, (v) permasalah daya saing produk dibandingkan dengan layanan pembiayaan lainya, (vi) permasalahan bonafiditas pengelolaan komoditas sistem resi gudang, (vii) permasalahan pengetahuan konsumen tentang 
pembiayaan sistem SRG, (viii) permasalahan informasi tentang komoditas pertanian, (ix) permasalahan kepercayaan pada sistem SRG, (x) permasalahan sistem birokrasi, (xi) permasalahan kebijakan pemerintah terkait sistem SRG, (xii) permasalahan infrastrukur pendukung sistem resi gudang dan (xiii) permasalah ketersediaan layanan pembiayaan. Permasalahan yang digambarkan tersebut di atas merupakan gabungan kelompok masalah tanpa memperhatikan perbedaan kepentingan tiap stakeholder dan hanya didasarkan pada kesamaan permasalahan. Kelompok permasalahan tersebut apabila disajikan berdasarkan kelompok institusi memberikan konsentrasi permasalahan yang berbeda-beda, sebagai contoh, kelompok konsumen pembiayaan SRG seperti kelompok petani akan berbeda dengan kelompok instutusi pembiayaan dan institusi pendukung pembiayaan SRG.

\section{Kelompok Masyarakat Produsen}

\section{Komoditas Pertanian}

Berdasarkan hasil pengamatan lapangan pada responden kelompok petani, terdapat sekitar 64 isu permasalahan yang berhasil diidentifikasikan sebagai penghambat berkembangnya pembiayaan komoditas sistem resi gudang (Gambar 5).
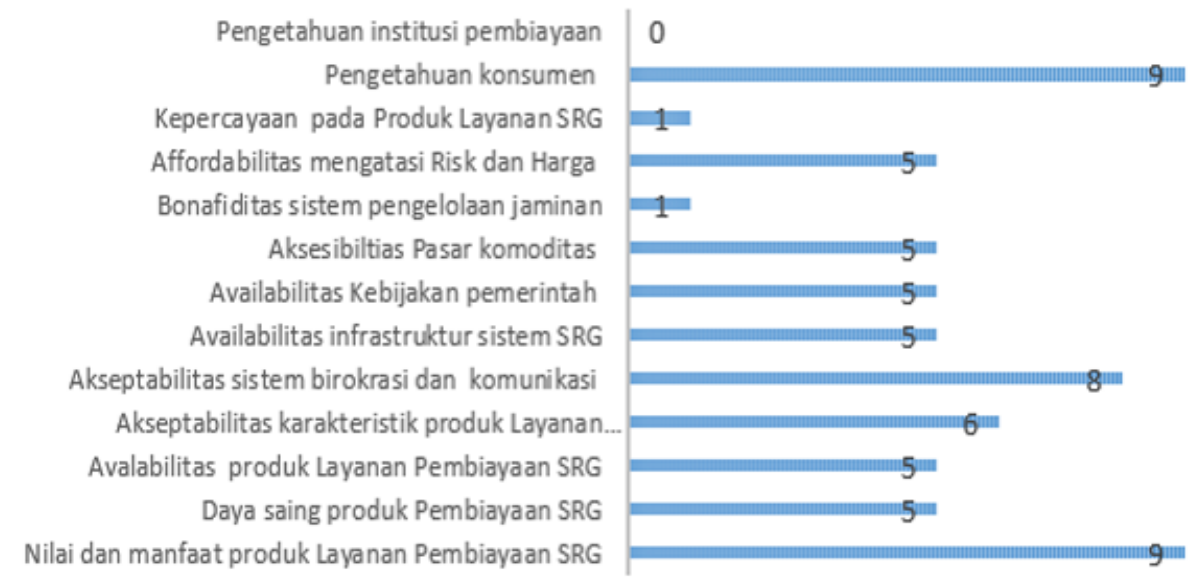

$\begin{array}{lllllllllll}0 & 1 & 2 & 3 & 4 & 5 & 6 & 7 & 8 & 9 & 10\end{array}$

\section{Gambar 5. Kendala Masyarakat Produsen Komoditas pada Pembiayaan SRG}

Berdasarkan pengelompokan pada Gambar 5, lima isu utama yang sebagai faktor permasalahan pada sistem resi gudang menurut kelompok masyarakat produsen adalah: (i) permasalahan nilai dan manfaat SRG yang belum sesuai harapan petani; (ii) permasalahan pengetahuan konsumen tentang pembiayaan sistem SRG; (iii) permasalahan sistem birokrasi; (iv) 
permasalahan karakteristik (struktur/ skim) produk pembiayaan komoditas; dan (v) beberapa faktor lainya yang memiliki jumlah temuan isu sama. Faktor lain tersebut adalah permasalahan risiko harga komoditas, permasalahan pasar komoditas, permasalahan kebijakan pemerintah terkait sistem SRG, permasalahan infrastruktur pendukung sistem resi gudang, permasalahan ketersediaan layanan pembiayaan, permasalahan daya saing produk dibandingkan dengan layanan pembiayaan lainya.

Berdasarkan kelompok isu diatas faktor nilai manfaat layanan pembiayaan merupakan permasalahan utama bagi kelompok tani. Hal tersebut sejalan dengan hasil penelitian Oktaviani et al. (2017) tentang implementasi sistem resi gudang di beberapa lokasi penghasil komoditas gabah dan kakao di Indonesia. Kelompok petani menilai pembiayaan sistem resi belum memberikan manfaat sesuai yang diharapkan. Masyarakat petani khususnya petani kecil mengharapkan sistem SRG dan sistem pembiayaannya yang dikembangkan memberikan manfaat yang nyata, terjangkau dan sesuai dengan karakteristik kelompok petani di
Indonesia yang relatif kecil. Selain nilai/ insentif, masalah pengetahuan tentang produk pembiayaan kurang memadai sehingga diperlukan distribusi informasi yang merata kepada masyarakat kelompok petani. Temuan tersebut sesuai dengan penelitian Listiani \& Haryotejo (2013) dan Bustamin (2014) dan Gunawan et al. (2019).

\section{Kelompok institusi sumber pembiayaan}

Berdasarkan hasil pengamatan lapangan pada responden kelompok lembaga pembiayaan, terdapat sekitar 81 isu permasalahan yang berhasil diidentifikasikan sebagai kendala berkembangnya pembiayaan komoditas sistem resi gudang (Gambar 6).

Lima isu utama yang dianggap menjadi penghambat perkembangan sistem resi gudang berdasarkan lembaga sumber pembiayaan (perbankan) adalah (i) permasalahan mengatasi risiko harga komoditas; (ii) permasalahan pasar komoditas; (iii) permasalahan nilai manfaat atau insentif mengembangkan produk layanan; (iv) masalah pengetahuan institusi pembiayaan tentang pembiayaan komoditas sistem SRG; dan (v) permasalahan karakteristik pembiayaan komoditas. 
Berdasarkan gambaran di atas lembaga pembiayaan mengangkat isu pengendalian risiko dan risiko harga komoditas sebagai bagian risiko pembiayaan dan risiko harga sebagai risiko pasar komoditas pertanian (Putri et al. 2013, Abubakar et al. 2017).
Permasalahan lainya adalah insentif pembiayaan terkait dengan risiko dan manfaat. Hal-hal tersebut menjadi faktor penghambat minat lembaga keuangan mengembangkan layanan pembiayaan komoditas pertanian sistem SRG.

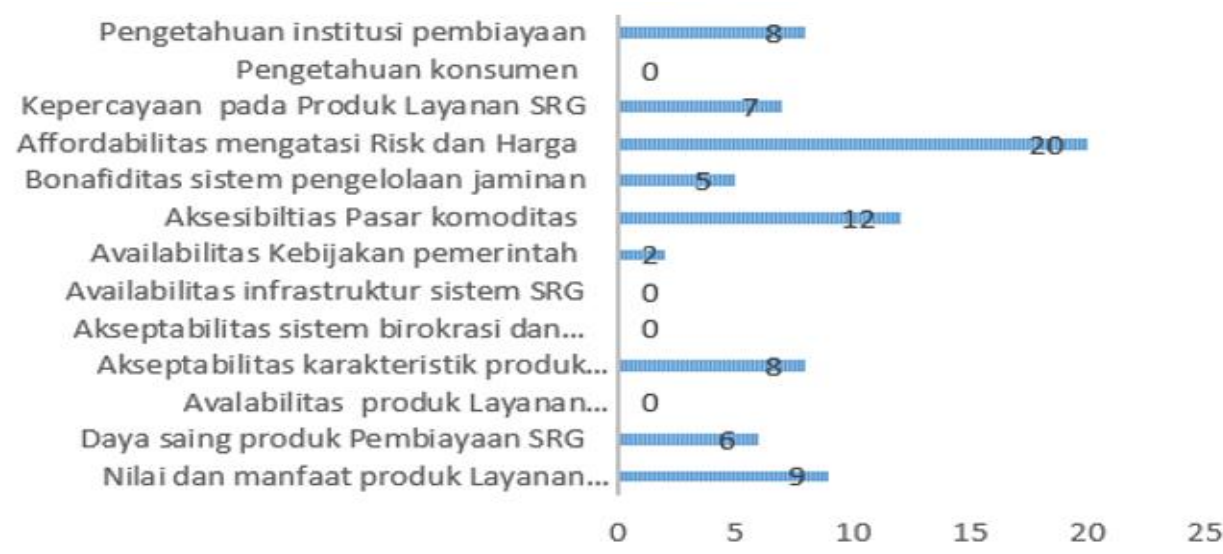

Gambar 6. Kendala Sumber Pembiayaan (Perbankan) pada Pembiayaan SRG

Kelompok Institusi Pengelola dan Pendukung Sistem Resi Gudang

Berdasarkan hasil penelitian terhadap institusi pengelola sistem resi gudang, terdapat 58 isu yang berhasil dikumpulkan dan dikelompokkan sebagai penghambat berkembangnya pembiayaan komoditas sistem resi gudang (Gambar 7).

Lima isu utama yang dianggap sebagai penghambat perkembangan pembiayaan komoditas pertanian sistem resi gudang berdasarkan institusi pengelola jaminan (collateral manager) adalah adalah: (i) permasalahan pengetahuan konsumen tentang pembiayaan sistem SRG; (ii) permasalahan kepercayaan pada sistem SRG; (iii) permasalahan bonafiditas pengelolaan komoditas sistem resi gudang, hal ini terkait dengan manajemen pengelolaan jaminan yang belum sesuai dengan ekspektasi sumber pembiayaan; (iv) permasalahan sistem birokrasi pada sistem resi gudang dan pembiayaan; dan (v) beberapa kelompok permasalahan yang memiliki intensitas isu yang sama. Permasalahan tersebut adalah kebijakan pemerintah yang 
penerapannya belum merata, permasalahan pasar penyangga untuk kepastian penjualan, dan infrastruktur pergudangan serta sistem pendukung yang belum memadai. Berdasarkan gambaran di atas, kelompok institusi pengelola gudang lebih menyoroti permasalahan pengetahuan konsumen SRG meliputi sumber pembiayaan dan konsumen pembiayaan SRG yang belum merata sebagai penghambat perkembangan pembiayaan komoditas pertanian sistem resi gudang di Indonesia
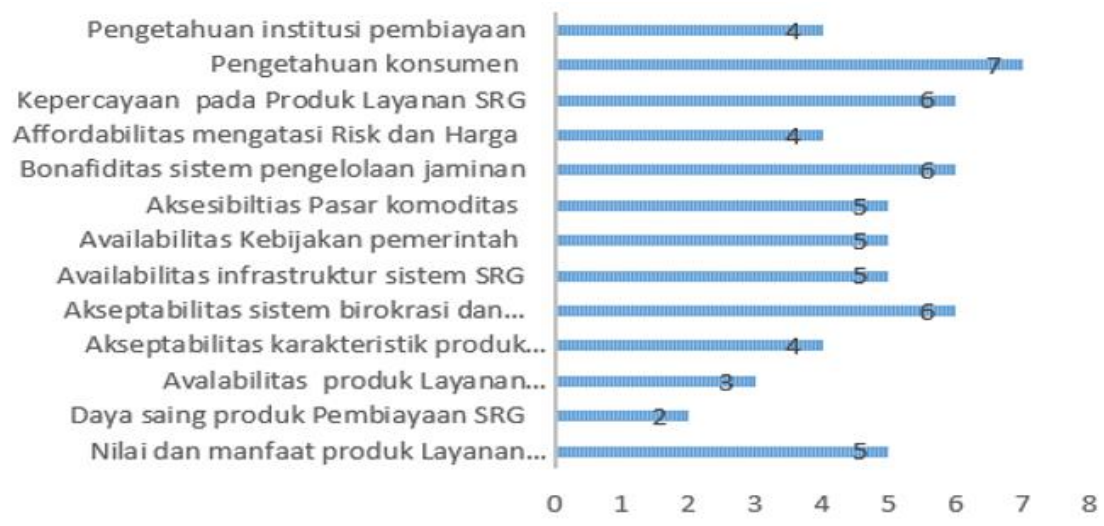

\section{Gambar 7. Kendala pada Pengelola Jaminan dan Institusi Pendukung Pengelola}

\section{Kelompok Pedagang atau Pengumpul Komoditas.}

Berdasarkan data hasil penelitian terhadap kelompok masyarakat pedagang dan pengumpul lokal komoditas pertanian, terdapat 46 isu yang berhasil dikumpulkan dan dikelompokkan sebagai penghambat berkembangnya pembiayaan komoditas sistem resi gudang (Gambar 8).

Lima isu utama yang dianggap sebagai faktor penghambat perkembangan pembiayaan komoditas pertanian sistem resi gudang berdasarkan pedagang dan pengumpul lokal tentang pembiayaan komoditas pertanian sistem resi gudang adalah: (i) permasalahan daya saing produk dibandingkan dengan layanan pembiayaan lainnya meliputi harga, kecepatan layanan dan kemudahan dan kenyamanan layanan; (ii) permasalahan karakteristik (struktur/skim) produk pembiayaan komoditas misalnya fitur atau skim produk sesuai karakteristik usaha perdagangan komoditas karena memiliki karakteristik tersendiri seperti siklus usaha dan siklus transaksi; (iii) 
permasalahan bonafiditas pengelolaan komoditas SRG; (iv) permasalahan pengetahuan konsumen tentang pembiayaan SRG karakteristik usaha komoditas; dan (v) permasalahan kebijakan pemerintah terhadap sistem resi gudang dan pembiayaannya yang masih dilakukan secara parsial dan belum mampu mengintegrasikan sistem resi gudang SRG dan CMA.

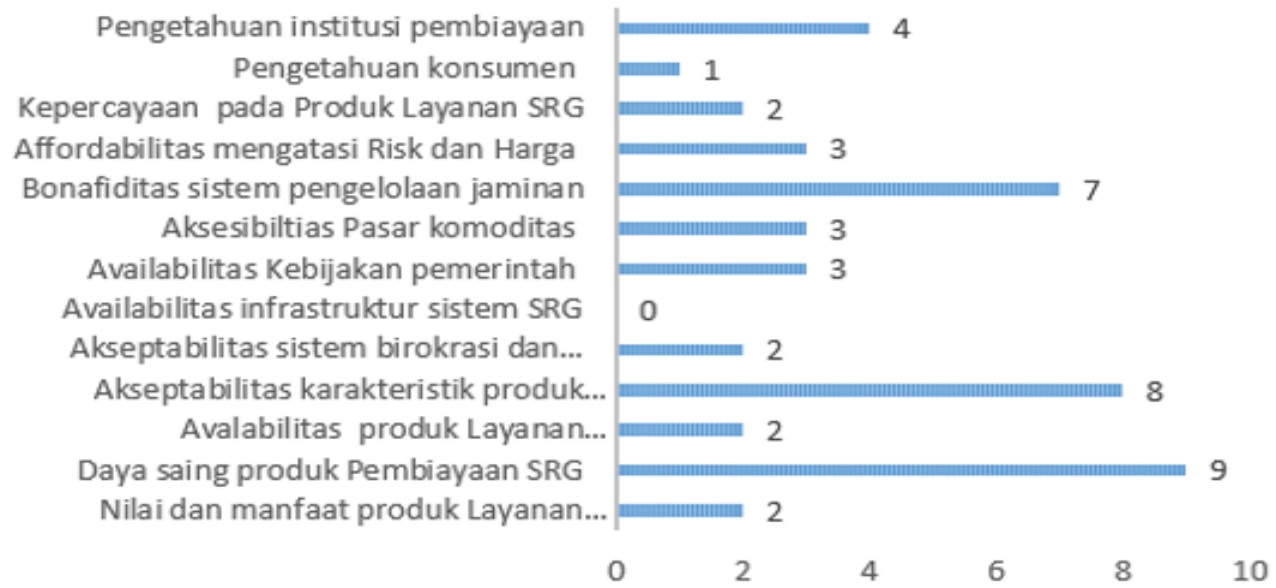

\section{Gambar 8. Kendala Pembiayaan Menurut Pengumpul atau Pedang Komoditas}

Berdasarkan gambaran di atas, kelompok pengumpul dan pedagang komoditas lebih menyoroti tentang nilai daya saing layanan pembiayaan dibandingkan dengan layanan pembiayaan lainya. Selain daya saing permasalahan pengetahuan konsumen SRG meliputi sumber pembiayaan dan konsumen pembiayaan SRG yang belum merata sebagai penghambat perkembangan pembiayaan komoditas pertanian sistem resi gudang di Indonesia.

Kesenjangan kepentingan konsumen dan sumber pembiayaan

Masalah pembiayaan komoditas SRG digambarkan berdasarkan kelompok stakeholder menunjukkan variasi permasalahan pada masingmasing stakeholder. Berdasarkan kelompok permasalahan, maka kendala pembiayaan komoditas tersebut dapat diklasifikasikan pada dimensi masalah penghambat sebagai berikut:

Kesenjangan nilai (value gaps)

Jarak antara nilai yang diharapkan dan dipersepsikan pada pembiayaan komoditas SRG terjadi pada semua stakeholder dengan intesitas yang berbeda. Arah nilai ditentukan oleh kepentingan yang berbeda pada stakeholder dan bergerak kearah yang berlawanan. Masyarakat petani atau gabungan petani kecil menginginkan 
pembiayaan yang dapat memahami posisi petani sebagai ekonomi lemah dan menginginkan adanya keberpihakan. Sementara masyarakat pengumpul atau pedagang dan institusi pembiayaan menentukan nilai layanan dari aspek nilai ekonomis. Masyarakat petani dan pengumpul menginginkan pembiayaan disusun dengan skema pembiayaan yang sesuai dengan karakteristik usahanya, namun institusi menyesuaikan skema pembiayaan dengan pertimbangan risiko.
Masyarakat petani dan pengumpul sebagai konsumen menghendaki kemudahan, dan kenyamanan serta harga yang terjangkau, sedangkan institusi sumber pembiayaan mempertimbangkan keseimbangan antara risiko dan keuntungan yang diperoleh dari produk pembiayaan. Kondisi di atas menggambarkan arah kepentingan masing-masing pihak yang cenderung bergerak pada arah yang berbeda dan bahkan terputus (disconnected) (Gambar 9).

\section{Sumber Pembiayaan}

\begin{tabular}{|l|l|}
\hline Nilai manfaat Sosial & Nilai komersial-economis \\
\hline Penerimaan produk berkarateristik pertanian & Produk Berbasis Risiko \\
\hline Ketersediaan dan Keterjangkauan (aksesibilitas) & Insentif produk (Biaya Transaksi) \\
\hline
\end{tabular}

\section{Gambar 9. Diskoneksi Kepentingan}

\section{Keterbatasan (Constraints)}

Permasalahan keterbatasan pada produk pembiayaan komoditas sistem resi gudang. Kendala keterbatasan pembiayaan yang direpresentasikan oleh petani sebagai kelompok penghasil komoditas menunjukkan kendala ketersediaan layanan (not always available), keterbatasan untuk memenuhi ketentuan (not always acceptable), keterbatasan mengakses layanan (not always accessible) dan keterbatasan kemampuan membayar biaya layanan (not always affordable). Availabilitas, akseptabilitas dan aksesibilitas dan affordabilitas misalnya ketersediaan layanan di lokasi sentra usaha tani, ketentuan-ketentuan produk, jarak layanan dan harga dan risiko produk.

Aspek-aspek diatas membatasi atau melampaui batas kemampuan konsumen untuk mendapatkan produk layanan. Sedangkan institusi pembiayaan juga dibatasi dengan kondisi ketersediaan infrastruktur 
pendukung, kemampuan memitigasi dan menanggung risiko dan kemampuan memenuhi batasan ekternal seperti regulasi seperti rasio kredit bermasalah yang berdampak pada rasio kesehatan bank. Keterbatasan lainya pada institusi pembiayaan adalah permasalahan institusi pendukung seperti pengelola jaminan, sistem pengelolaan, permasalahan pasar komoditas dan kemampuan finansial untuk membangun sistem yang mampu mengintegrasi atau mengkoneksi antar elemen atau stakeholder di sekitar pembiayaan sistem resi gudang dengan sumber pembiayaan.

Asimetri informasi (Assimetry of Information)

Pada kelompok konsumen atau petani tidak mendapatkan informasi dan pengetahuan yang memadai tentang produk pembiayaan SRG. Sedangkan institusi sumber pembiayaan kurang memahami karakteristik usaha pertanian. Ketidakseimbangan informasi secara teori memengaruhi persepsi kedua belah pihak pada produk layanan.

Perbedaan pengetahuan juga terjadi pada institusi pendukung seperti institusi pengelola gudang, pengelola jaminan dan institusi terkait lainnya. Masing-masing stakeholder memiliki tingkat penerimaan informasi dan pengetahuan dan masing-masing memberikan penilaian sesuai dengan pengetahuan dan informasi yang dimilikinya. Permasalahan seperti digambarkan di atas dan perbedaan kepentingan stakeholder sistem yang digambarkan sebagai kesenjangan nilai (value gaps), keterbatasan dan pembatasan (constraints) dan ketidakseimbangan informasi (asymmetry of information). Tetapi berdasarkan identifikasi isu yang ditemukan pada penelitian kendala pembiayaan yang disebabkan oleh pembatasan dan keterbatasan lebih dominan (Gambar 10).

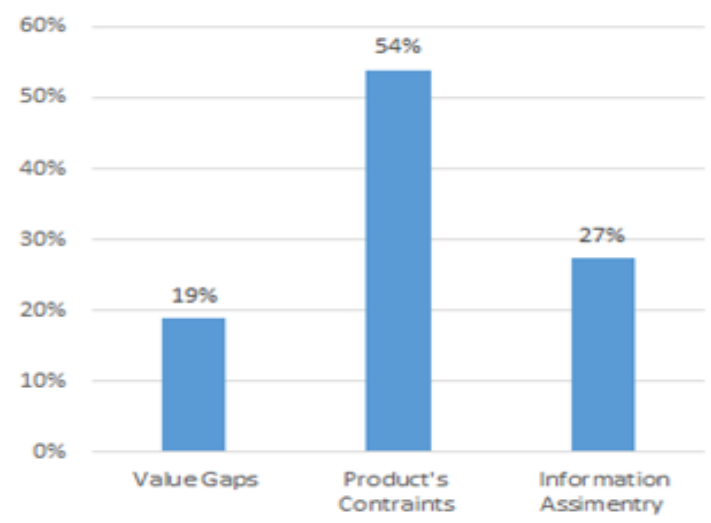

Gambar 10. Klasifikasi Kendala Pembiayaan Komoditas Sistem Resi Gudang

KESIMPULAN DAN REKOMENDASI KEBIJAKAN

Berdasarkan hasil identifikasi, pengelompokan, dan klasifikasi permasalahan pembiayaan komoditas 
pertanian SRG pada komoditas kopi, lada, beras dan jagung, penghambat berkembangnya pembiayaan komoditas pertanian SRG di Indonesia dipengaruhi oleh multi faktor yang kompleks seperti:

Pertama, ketidaksesuaian atau kesenjangan nilai (value gaps) produk yang dibangun apabila ditinjau dari karakteristik usaha, khususnya petani kecil yang masih sulit dijangkau melalui pembiayaan komoditas sistem resi gudang. Lingkungan usaha kecil menghendaki adanya keberpihakan atau pembiayaan bernilai sosial dalam pembiayaan komoditas pertanian. Sedangkan usaha skala menengan dan besar seperti pengumpul dan pedagang menghendaki nilai ekonomis sebagai pertimbangan utama. Kedua, keterbatasan yang bersumber dari berbagai stakeholder dan lingkungan SRG dan pembiayaan misalnya ketersediaan produk, kesesuaian skema, keterjangkauan lokasi dan kesanggupan memenuhi harga dan ketentuan. Ketiga, asimetri informasi atau ketidakseimbangan informasi meliputi kecukupan informasi dan pengetahuan stakeholder pada pembiayaan SRG. Ketiga aspek kendala diatas merupakan elemen kendala pada produk pembiayaan sistem resi gudang. Kendala tersebut harus dapat atasi atau diperkecil untuk mendorong kelangsungan produk diterima sesuai karakteristik lingkungan pasar.

Permasalahan pembiayaan SRG pada penelitian ini memberikan gambaran kompleksitas permasalahan pembiayaan komoditas sistem resi gudang di Indonesia. Untuk melengkapi penelitian ini dibutuhkan penelitianpenelitian lainya misalnya penilaian sistem resi gudang dan pembiayaannya pada komoditas unggulan lainya, penilaian berdasarkan skala usaha dan nilai ekonomis (economic of scale) dari layanan pembiayaan yang disesuaikan dengan kondisi lingkungan petani yang memiliki keunikan tersendiri. Kendala pembiayaan tersebut harus dapat atasi atau diperkecil untuk mendorong kelangsungan pembiayaan pertanian sistem resi gudang di Indonesia. Sebagai kelanjutan dari temuan pada penelitian ini dibutuhkan strategi pemecahan yang dapat dikembangkan untuk meminimalisasi kendala dan mendorong kelangsungan dan keberlanjutan produk layanan pembiayaan itu berkembang sesuai karakteristik usaha di Indonesia. 
UCAPAN TERIMA KASIH

Penulis mengucapkan terima kasih kepada para dosen pembimbing dan kepada civitas akademika Sekolah Bisnis Institut Pertanian Bogor atau IPB University atas dukungan dalam penulisan artikel ini. Ucapan terima kasih juga disampaikan kepada jajaran Badan Pengkajian dan Pengembangan Perdagangan, serta para reviewer atas masukannya untuk penyempurnaan artikel ini.

\section{DAFTAR PUSTAKA}

Abubakar, I., Hakim, D.B. dan Asmarantaka R.W. (2017). Struktur Perilaku dan Kinerja Biji Kakao di kabupaten Parigi Moutong, Bogor: Sekolah Pascasarjana, Institut Pertanian Bogor.

Ashari. (2012). Potensi dan Kendala Sistem Resi Gudang Untuk Mendukung Pembiayaan Usaha Pertanian di Indonesia. Pusat Sosial Ekonomi dan Kebijakan Pertanian, Bogor.

Becchetti, L \& Conzo, P. (2009). Creditworthiness as a signal of trustworthiness: field experiment in microfinance and consequences on causality in impact studies.

Bustamin. (2014). Management Strategy of Management Strategy of Warehouse Receipt System on coconut commodities, Indonesia.

Capacio, Emmanuel, Tulder, R. (2018). Breaking barriers in agriculture financing: Enhancing the inclusiveness and sustainability of agriculture value chains, University of Philipines.

Coulter \& Onumah. (2002). The role of warehouse receipt systems in enhanced commodity marketing and rural livelihoods in Africa, Natural
Resources Institute, Central Avenue, Chatham Maritime, Kent ME4 4TB, UK.

Listiani, N., Haryotejo, B. (2013). Implementasi Sistim Resi Gudang (SRG) pada komoditas jagung, Pusat Penelitian Ekonomi (P2E) LIPI, 2013

Gashayie \& Singh. (2015). "Agricultural Finance Constraints and Innovative Models Experience for Ethiopia: Empirical Evidence from Developing Countries, Punjabi University, India.

Gunawan, E., Kuwornu, J. and Nguyen ADLT. (2019). Farmers' Perceptions of the Warehouse Receipt System in Indonesia, Department of Food, Agriculture, and Bioresources, School of Environment, Resources and Development, Asian Institute of Technology, Klong Luang, Pathumthani 12120, Thailand.

Hananu, B., Hanan, A.dan Zakaria, H. (2015). Factors Influencing Agricultural Credit Demand in Northern Ghana. African Journal of Agricultural Research, 10(7), 645652.

https://doi.org/10.5897/AJAR2014.

James \& Michael. (1998). The Constraint Management Handbook, Boca Raton, Florida

Kotler, P. \& Keller, K.L. (2009). Marketing Management. 13rd edition. New Jersey (US): Pearson International Edition.

Listiani, N. \& Haryotejo, B. (2013). Implementasi Sistim Resi Gudang (SRG) pada komoditas jagung, Pusat Penelitian Ekonomi (P2E) LIPI, 2013.

Mahanta, D. (2012). Review of Warehouse Receipt as an Instrument for Financing in India, International Journal of Scientific and Technology Research Vo. 1, Issue 9.

Miranda, M.J, Francis Mulangu, F.M. dan Kemeze, F.H. (2017). Warehouse Receipt Financing for Smallholders in Developing Countries: Short on Logic, 
Long on Imagination, the Ohio State University, Columbus.

Nyanzu, F. \& Quaidoo, M. (2017). Access to Finance Constraint and SMEs Functioning in Ghana, Mississippi State University, US. University of Cape Coast, Ghana.

Oktaviani, R. Mulatsih, S., Anggraeni, L and Dilla S. Sati, Y.R., Tejaningrum, I., Ramdan, A., Imamah H., Lestari D.A. (2017). Kajian Peningkatan Pemanfaatan Sistem Resi Gudang, Bank Indonesia, 2017.

Ohmae dan Kenichi (1982). The art of Japanese business, The mind of strategy, Jepang, 1982.

Purnama. (2006). Manajemen Kualitas, Perspektif Global, Edisi Pertama. Ekonisia Fakultas Ekonomi.

Reyes, A., Lensink. R., Kuyvenhoven A, dan Moll H, (2012) "Impact on Access to Credit on Farm Productivity of Fruit and Vegetable Grower in Chile": http://ageconsearch.umn.edu/bitstrea $\mathrm{m} / 126217 / 2 /$ Impact of access to credit .pdf.

Rutten, L. (2015). The use of warehouse receipt finance in agriculture in transition countries, World Grain Forum 2009, St. Petersburg / Russian Federation 6-7 June 2009 https: //www.researchgate.net/publication/2 42578672.

Sheth, J., N. \& Sisodia, R., S. (2012). The $4 A$ 's of Marketing. Creating Value for
Customers, Companies, and Society. New York. Routledge

Siadari. K, Maarif. S, Arifin B. dan Rangkuti Z. (2021). Characteristics of Agricultural Commodities Financing Base on Warehouse Receipt System in Indonesia. The International Institute for Science, Technology, and Education (IISTE).

Stiglitz, J.E. \& Weiss A. (1981). Credit Rationing in Market with Imperfect Information, The American Economic Review, June 1981.

Suryani. E, Erwidodo dan Setiadjie I. (2014). Sistem Resi Gudang di Indonesia Antara Harapan dan Kenyataan. Institut Pertanian Bogor.

Sutak, P. (2008). Structured Commodity Finance, Agroinform Publishing House, Budapest Budapest, 2008

Swamy, D. \& Dharani, M. (2016). Analyzing the agricultural value chain financing: approaches and tools in India.

Varangis, P. \& Geours, J.S. (2013). "Warehouse Finance and Warehouse Receipt Systems: A Guide for Financial Institutions in Emerging Economies". Technical Report, The World Bank, Washington, DC.

Varangis, P., \& Larson, D. (2002). "How Warehouse Receipts Help Commodity Trading and Financing." World Bank, Washington, DC. 2 